\title{
The role of luteinizing hormone-releasing hormone in the diagnosis of constitutional delayed puberty
}

\author{
Julius SAGEL \\ M.B., Ch.B., F.C.P.(S.A.) \\ LARRY A. Distiller \\ M.B., B.Ch., F.C.P.(S.A.) \\ BARRY I. JOFFE \\ M.B., B.Ch., M.R.C.P.
Division of Endocrinology, Departments of Medicine and Radioisotopes, University of the Witwatersrand and Johannesburg General Hospital, Johannesburg, South Africa

\begin{abstract}
Summary
The presumptive diagnosis of constitutional delayed adolescence is difficult to substantiate. Clinical examination and routine biochemical testing are not sufficient to exclude isolated gonadotrophin deficiency. Seven males are reported who presented with delayed puberty. These patients were given $100 \mu$ g luteinizing hormone-releasing hormone (LH-RH) intravenously, and the luteinizing hormone (LH) and follicle stimulating hormone (FSH) responses were measured.

Three of four males who were completely prepubertal (Stage 1) had a normal adult male response. These three patients have progressed further into puberty several months after this diagnostic test. The fourth patient in stage 1 puberty had a prepubertal LH response. A year later the response became adult in type, and 3 months thereafter stage 2 puberty was evident.
\end{abstract}

The LH response to LH-RH thus appears to have some prognostic value in the assessment of males presenting with delayed puberty.

THE diagnosis of delayed puberty can be made in males who, by the age of 15 years, have not yet started developing secondary sex characteristics (Paulsen, 1974). The problem arises in differentiating this group with constitutional delayed adolescence from those with isolated gonadotrophin deficiency. Since the majority of these patients belongs to the former group and thus represents variants of normality who will eventually become pubescent, the attitude of 'wait and watch' has been frequently adopted. The clomiphene test, although useful for studying the hypothalamic-pituitary-testicular axis in adult males, does not help in the diagnosis of delayed puberty, since a gonadotrophin response to clomiphene only occurs from late puberty onwards (Nankin, Yanaihara and Troen, 1971; Kulin, Reiter and Bridson, 1971) and the test is negative in prepubertal boys, early puberty (Paulsen, 1974; Nankin et al., 1971) and in states of isolated gonadotrophin deficiency. However, the assurance of a good prognosis and the decision whether or not to implement $\vec{A}$ therapeutic measures is dependent upon hormonal $O$ confirmation of the clinical diagnosis.

The availability of luteinizing hormone-releasing hormone (LH-RH) provides a method of assessing the hypothalamic-pituitary-testicular axis in an attempt to elucidate this problem. We wish to reporf our experience with the use of LH-RH in seven males presenting with features of 'delayed puberty'.

\section{Subjects and methods}

Patients presenting at the Endocrine Clinic, Johannesburg General Hospital, with delayed development of secondary sexual characteristics and shortness of stature are routinely assessed both clinically and biochemically in order to exclude organic causes of their presentation. The biochemical tests performed include a full blood count, blood urea and creatinine, in vitro thyroid function tests (serum tetraiodothyronine and triiodothyronine resin uptake) and the growth hormone and cortisol response to insulin-induced hypoglycaemia. When these parameters have been established as normal, the patients are considered to have 'delayed puberty'.

The clinical features of seven patients with this presentation are shown in Table 1. Staging of sexual development was according to the system of Tanner (1962). Boys in Stage 1 were completely prepubertal, while those in Stage 2 had enlargement of the scrotum and testis. None of the seven patients had attained Stage 3 of sexual development (enlargement of penis and further growth of testis and scrotum) despite all being over 15 years of age. Figure 1 demonstrates the relationship between the chronological ages, the bone ages and the heights of these patients. As expected, the height of all these patients is below the third percentile. However, when the height is related to bone age, in all but one of the patients it then falls 
TABLE 1. Clinical features of patients with delayed puberty at time of presentation

\begin{tabular}{cccccc}
\hline $\begin{array}{c}\text { Case } \\
\text { no. }\end{array}$ & $\begin{array}{c}\text { Chronological } \\
\text { age (years) }\end{array}$ & $\begin{array}{c}\text { Bone age } \\
\text { (years) }\end{array}$ & $\begin{array}{c}\text { Height } \\
(\mathrm{cm})\end{array}$ & $\begin{array}{c}\text { Weight } \\
(\mathrm{kg})\end{array}$ & $\begin{array}{c}\text { Stage of } \\
\text { puberty }\end{array}$ \\
\hline 1 & 16 & 15 & 157 & $36 \cdot 7$ & 2 \\
2 & 16 & 13 & 152 & $35 \cdot 6$ & 2 \\
3 & 15 & 14 & 151 & $30 \cdot 8$ & 1 \\
4 & 16 & 14 & 147 & $40 \cdot 8$ & 1 \\
5 & $15 \cdot 5$ & 12 & 137 & $33 \cdot 1$ & 1 \\
6 & $16 \cdot 75$ & 15 & 145 & $38 \cdot 0$ & 2 \\
7 & $16 \cdot 75$ & $14 \cdot 5$ & 153 & $35 \cdot 0$ & 1 \\
\hline
\end{tabular}

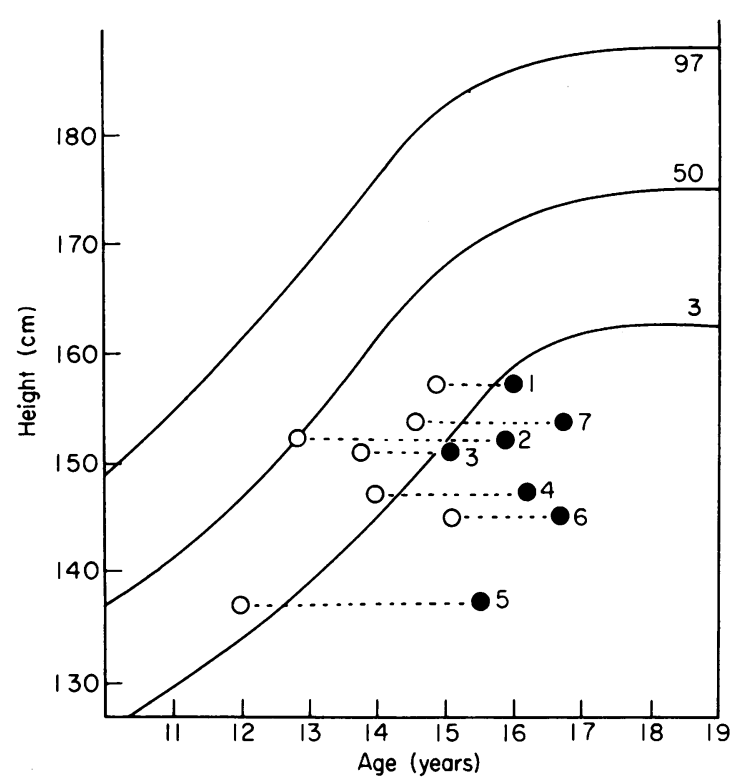

FIG. 1. Chronological (O) and bone (O) ages of the seven patients related to their height on the standard male percentile charts.

within the third percentile, demonstrating the general delayed development seen in this condition.

Synthetic LH-RH (Ayerst) $100 \mu \mathrm{g}$ was administered intravenously over $30 \mathrm{sec}$ to each patient. Blood samples were collected before the injection and 30,60 and $120 \mathrm{~min}$ thereafter. The serum was assayed for luteinizing hormone (LH) and follicle stimulating hormone (FSH) in duplicate by specific double antibody radioimmunoassays according to the method of Reuter, Hendrick and Franchimont (1973). All the samples for individual patients were measured in the same assay, and the results were expressed as $\mathrm{ng} / \mathrm{ml}$ using reference preparations which have been standardized in terms of LER-907. The coefficient of variations for the LH and FSH assays were $7.8 \%$ and $12 \%$ respectively.

Since it has been shown that there is no significant difference between the LH response to LH-RH in pubertal and adult males (Roth et al., 1972), these results were compared to those obtained in a group of sixteen normal young adult males, ages 21-30 years.

\section{Results}

The gonadotrophin responses to LH-RH in the seven patients studied are illustrated in Fig. 2. Of the four patients who were prepubertal (i.e. Stage 1),

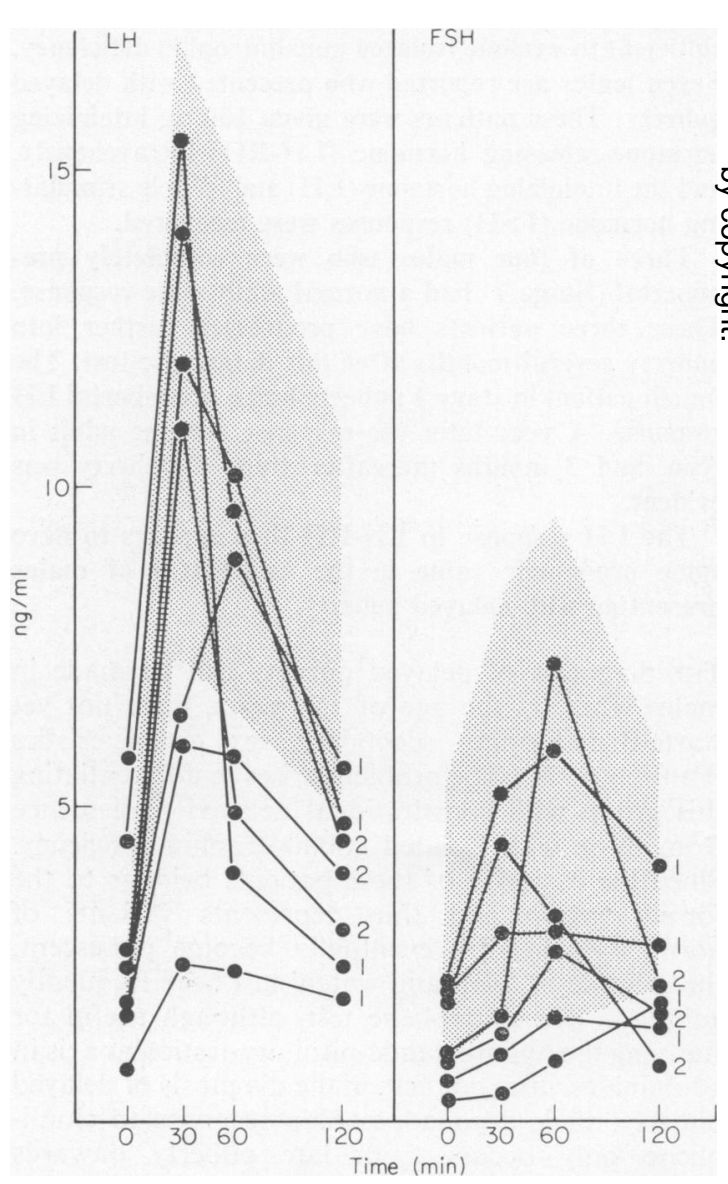

FIG. 2. LH and FSH responses to $100 \mu \mathrm{g}$ LH-RH in the seven patients on presentation. 浀, Adult male. Controls: mean \pm s.d. 
three had an LH response to LH-RH similar to that obtained in the adult male control group. The three patients with Stage 2 puberty all had adequate $\mathrm{LH}$ responses to LH-RH. The FSH response to releasing hormone is within normal adult male limits in all cases.

The pubertal development of the patients during a follow-up period varying from 4 to 15 months is shown in Table 2. All patients had advanced in pubertal development.

TABLE 2. Follow-up on the patients studied

\begin{tabular}{ccc}
\hline $\begin{array}{c}\text { Case } \\
\text { no. }\end{array}$ & $\begin{array}{c}\text { Period of follow-up } \\
\text { (months) }\end{array}$ & $\begin{array}{c}\text { Stage of puberty at } \\
\text { most recent assessment }\end{array}$ \\
\hline 1 & 8 & 3 \\
2 & 6 & 3 \\
3 & 13 & 3 \\
4 & 10 & 3 \\
5 & 15 & 2 \\
6 & 8 & 2 \\
7 & 4 & 2 \\
\hline
\end{tabular}

The one patient in Stage 1 puberty (Case 5) who had an inadequate LH response initially was restudied with LH-RH after 1 year, when he was clinically still prepubertal. The initial and repeated LH response to LH-RH are illustrated in Table 3. Three months later the patient had clinically entered Stage 2 puberty.

\section{Discussion}

It has been shown that both LH and FSH secretion occur in prepubertal children (Burr et al., 1970). The onset of puberty appears to be determined by a decrease in the inhibitory influences of circulating sex steroids on the hypothalamic-pituitary-axis (Kulin, Grumbach and Kaplan, 1972). It has been shown that the serum gonadotrophin level increases before the physical signs of sexual maturation occur (Johanson et al., 1969; Raiti et al., 1969). However, to utilize this biological phenomenon in the differentiation of true delayed puberty from isolated gonadotrophin deficiency serial 6-monthly gonadotrophin estimations are necessary (Root, 1973). In addition, plasma sampling during sleep is more critical than during waking hours in evaluating gonadotrophin function in children, because of a marked augmentation of LH secretion associated with sleep in early pubertal children (Boyar et al., 1974). Diagnosis and prognostication are thus uncertain and delayed when based on isolated serial gonadotrophin estimations.

It has previously been demonstrated that prepubertal boys have a six to seven times lower LH response to LH-RH than clinically pubertal and adult males (Roth et al., 1972). However, the time of transition of the $\mathrm{LH}$ response to releasing hormone is not clear. In three of the seven patients in this study an adequate (pubertal or adult type) LH response was obtained in the absence of any clinical $\vec{\circ}$ evidence of sexual maturation. These patients all entered clinical puberty within 10 months. Only one of our patients had a frankly prepubertal LH response to LH-RH (Case 5) and at follow-up was found to develop an adult $\mathrm{LH}$ response 3 months before clinical evidence of Stage 2 puberty appeared. It therefore appears that a positive $\mathrm{LH}$ response to LH-RH has important diagnostic and prognostic significance in the approach to the patient with delayed puberty. We are aware, however, that occasionally in patients with isolated gonadotrophin deficiency an LH response to LH-RH has been reported (Mortimer et al., 1973).

\section{Acknowledgments}

We would like to thank Dr E. S. Polakow and Ayer International (South Africa) for the supply of LH-RH.

\section{References}

Boyar, R.M., Rosenfield, R.S., Kaplan, S., Finkelstein J.W., Roffwarg, H.P., Weitzman, E.D. \& Hellman, L, (1974) Simultaneous augmented secretion of luteinizing hormone and testosterone during sleep. Journal of Clinical Investigation, 54, 609.

Burr, I.M., Sizonenko, P.C., Kaplan, S.L. \& Grumbach, M.M. (1970) Hormonal changes in puberty. I. Correlation of serum luteinizing hormone and follicle stimulating hormone with stages of puberty, testicular size and bone age in normal boys. Pediatric Research, 4, 25.

Johanson, A.J., Guyda, H.J., Light, C., Migeon, C.J. \& BLIzZARD, R.M. (1969) Serum luteinizing hormone by radioimmunoassay in normal children. Journal of Pediatrics, 74, 416.

Kulin, H.E., Reiter, E.O. \& Bridson, W.E. (1971) Pubertal maturation of the gonadotrophin stimulatory response to clomiphene. Case Report. Journal of Clinical Endocrinology and Metabolism, 33, 551.

Kulin, H.E., Grumbach, M.M. \& Kaplan, S.J. (1972) Gonadalhypothalamic interaction in prepubertal and pubertal man: Effect of clomiphene citrate on urinary follicle-stimulating hormone and luteinizing hormone and plasma testosterone. Pediatric Research, 6, 162.

TABLE 3. Gonadotrophin response to $\mathrm{LH}-\mathrm{RH}$ on presentation and again 1 year later (Case 5)

\begin{tabular}{lccccccccc}
\hline & \multicolumn{4}{c}{ LH $(\mathrm{ng} / \mathrm{ml})$} & & \multicolumn{3}{c}{ FSH $(\mathrm{ng} / \mathrm{ml})$} \\
\cline { 2 - 4 } \cline { 8 - 10 } Time (min) & 0 & 30 & 60 & 120 & & 0 & 30 & 60 & 120 \\
\hline August 1973 & $0 \cdot 9$ & $2 \cdot 7$ & $2 \cdot 6$ & $2 \cdot 1$ & & $2 \cdot 1$ & $3 \cdot 0$ & $3 \cdot 1$ & $2 \cdot 9$ \\
September 1974 & $5 \cdot 2$ & $11 \cdot 4$ & $7 \cdot 4$ & $7 \cdot 3$ & & $0 \cdot 7$ & $2 \cdot 4$ & $2 \cdot 7$ & $1 \cdot 5$ \\
\hline
\end{tabular}


Mortimer, C.H., Besser, G.M., MCNeilly, A.S., Marshall, J.C., Harsoulis, P., Tunbridge, W.M.G., Gomez-Pan, A. \& HaLL, R. (1973) Luteinizing hormone and follicle stimulating hormone-releasing hormone test in patients with hypothalamic-pituitary-gonadal dysfunction. British Medical Journal, 4, 73.

Nankin, H.R., Y.naihara, T. \& Troen, P. (1971), Response of gonadotrophins and testosterone to clomiphene stimulation in a pubertal boy. Journal of Clinical Endocrinology and Metabolism, 33, 360.

Paulsen, C.A. (1974) The testis. Williams Textbook of Endocrinology, 5th edn, p. 354. W. B. Saunders Co., Philadelphia, London, Toronto.

Raiti, S., Johanson, A.J., Light, C., Migeon, C.J. \& BLIzZARD, R.M. (1969) Measurement of immunologically reactive follicle stimulating hormone in serum of normal male children and adults. Metabolism, 18, 234.
Reuter, A.M., Hendrick, J.C. \& Franchimont, P. (1973) Mise au point d'un dosage radio-immunologique rapide des gonadotrophines. Annales de biologie clinique, 31, 479.

Root, A.W. (1973) Endocrinology of puberty. II. Aberrations of sexual maturation. Journal of Pediatrics, 83, 187.

Roth, J.C., Kelch, R.P., KaPlan, S.L. \& GrumbaCh, M.M. (1972) FSH and LH response to luteinizing hormonereleasing factor in prepubertal and pubertal children, adult males and patients with hypogonadotropic and hypergonadotropic hypogonadism. Journal of Clinical Endocrinology and Metabolism, 35, 926.

TANNER, J.M. (1962) Development of the reproductive system. In: Growth at Adolescence, 2 nd edn, p. 32. Blackwell, Oxford. 